\title{
Heart pathologies in dolphins stranded along the northwestern Italian coast
}

\author{
F. E. Scaglione ${ }^{1, *}$, E. Bollo ${ }^{1}$, P. Pregel ${ }^{1}$, L. Chiappino ${ }^{1}$, A. Sereno ${ }^{1}$, W. Mignone ${ }^{2}$, \\ R. Moschi ${ }^{3}$, F. Garibaldii ${ }^{4}$, C. Tittarelli ${ }^{2}$, F. Guarda ${ }^{1}$ \\ ${ }^{1}$ Dipartimento di Scienze Veterinarie, Università degli Studi di Torino, 10095 Grugliasco, Italy \\ ${ }^{2}$ Istituto Zooprofilattico del Piemonte, Liguria e Valle d'Aosta, Sezione di Imperia, 18100 Imperia, Italy \\ ${ }^{3}$ ASL 1 imperiese, Bussana di Sanremo, 18038 Sanremo, Italy \\ ${ }^{4}$ Dipartimento di Scienze della Terra, dell'Ambiente e della Vita, Università degli Studi di Genova, 16132 Genova, Italy
}

\begin{abstract}
Nine striped dolphins Stenella coeruleoalba and 1 bottlenose dolphin Tursiops truncatus stranded along the Ligurian Sea coast of Italy were necropsied between February 2011 and April 2012. Macroscopic and histological findings were observed in the hearts of all animals and included saccular aneurysms of the pulmonary trunk $(n=3)$, cirsoid aneurysms $(n=1)$, right ventricular dilation $(\mathrm{n}=1)$ associated with hypoplasia of the tricuspid chordae $(\mathrm{n}=1)$, valvular fibrosis $(\mathrm{n}=3)$, mitral leaflet thickening $(\mathrm{n}=1)$, left ventricular hypertrophy $(\mathrm{n}=1)$, lymphocytic myocarditis $(\mathrm{n}=1)$, and Lambl's excrescences $(\mathrm{n}=4)$. To our best knowledge Lambl's excrescences, aneurysm of the pulmonary trunk, and cirsoid aneurysms have not previously been described in marine mammals, and some of these findings should be taken into account as possible causes of dolphin morbidity, mortality, and stranding.
\end{abstract}

KEY WORDS: Aneurism $\cdot$ Lambl's excrescences $\cdot$ Stenella coeruleoalba $\cdot$ Tursiops truncatus

\section{INTRODUCTION}

Little is known about the development of and pathology affecting cetacean hearts (Sedmera et al. 2003), since they have been poorly studied in marine mammals. The few cases of heart disease reported in cetaceans include infections (Guzmán-Verri et al. 2012), parasites (Jardine \& Dubey 2002), and malformations (Slijper 1961, Gray \& Conklin 1974, Neurohr 1982, Troncone \& Zizzo 1994, Powell et al. 2009). Bossart et al. (2007) reported cases of myocardial degeneration and moderate myocarditis in stranded sperm whales (Kogia spp.), and myocardial contraction band necrosis was identified by Turnbull \& Cowan (1998) in $100 \%$ of 52 cetaceans of different species stranded between 1991 and 1996. A low incidence of abnormal cardiac development in cetaceans has been reported (Powell et al. 2009).
Congenital anomalies, including heart malformations, are rarely observed in Atlantic bottlenose dolphins Tursiops truncatus and other delphinids, and are mainly reported in stillborn or neonate cetaceans. A case of right ventricular hypertrophy, ventricular septal defect, aortic dilation, atrial septal defect, subvalvular pulmonic stenosis, and hypoplasia of the pulmonary artery and mitral valve were described in a stranded neonate $T$. truncatus by Powell et al. (2009). Gray \& Conklin (1974) described a transposition of the pulmonary artery and aorta associated with interventricular foramen in an unborn bottlenose dolphin fetus. Persistent ductus arteriosus, atrial septal defect, and right ventricular hypertrophy were reported in a $7 \mathrm{~d}$ old captive-born T. truncatus by Neurohr (1982). While there have been individual observations, reports of cardiac pathologies in multiple animals have not 
been well documented. The aim of this study was to evaluate cardiac pathology in stranded dolphins.

\section{MATERIALS AND METHODS}

Nine striped dolphins Stenella coeruleoalba ( 7 males and 2 females) and 1 male bottlenose dolphin stranded along the Ligurian Sea coast of Italy between February 2011 and April 2012 were examined (Table 1). Age classes were determined (subadults: case nos. 6 and 10; adults: all other animals), and field necropsies were performed on all animals to ascertain the cause of death. Intact hearts submitted to the Department of Veterinary Science of the University of Turin (Italy) were fixed in $10 \%$ neutral buffered formalin ( $\mathrm{pH} 7$ ). The hearts were examined according to Virchow (1880) and Finkbeiner et al. (2009), and lesions were systematically described and graded. For histological investigations, tissue samples from the hearts were wax-embedded, sectioned at $4 \mu \mathrm{m}$ using a microtome (Leica Microsystems), and stained with hematoxylin and eosin (HE) and Weigert-Van Gieson (WVG) stains.

\section{RESULTS}

No gross lesions were observed in case no. 6. In 6 animals, parasitic nodules were detected in different anatomic locations (peritoneum: cases 1 and 3 ; liver: case 1 ; skeletal muscle: case 2; omentum: cases 1 and 6 ; pericardium: case 2 ; intestine: case 6 ; lungs: cases 8 and 10). In case 4 , the left lung had emphysema. In

Table 1. Necropsy findings, gross and microscopic heart lesions. NC = not collected

\begin{tabular}{|c|c|c|c|c|c|c|c|c|}
\hline No. & Species & $\operatorname{Sex}$ & Age & Length & Weight & Necropsy findings & Gross heart lesions & $\begin{array}{c}\text { Microscopic heart } \\
\text { lesions }\end{array}$ \\
\hline 1 & \begin{tabular}{|l|} 
Stenella \\
coeruleoalba
\end{tabular} & M & Adult & $194 \mathrm{~cm}$ & $73 \mathrm{~kg}$ & $\begin{array}{l}\text { Marble spleen; adrenal hypo - } \\
\text { plasia; multifocal, irregularly } \\
\text { distributed, 2-mm parasitic } \\
\text { nodules scattered throughout } \\
\text { peritoneum, liver and } \\
\text { omentum }\end{array}$ & $\begin{array}{l}\text { Right ventricular } \\
\text { dilation; aneurysm of } \\
\text { right sinus of Valsalva; } \\
\text { hypoplasia of tricuspid } \\
\text { chordae; tricuspidal } \\
\text { fibrosis; interventri- } \\
\text { cular white spot }\end{array}$ & $\begin{array}{l}\text { Aneurysm of right } \\
\text { sinus of Valsalva; } \\
\text { tricuspid endo- } \\
\text { cardiosis; Lambl's } \\
\text { excrescences; } \\
\text { lymphocytic } \\
\text { myocarditis }\end{array}$ \\
\hline 2 & $\begin{array}{l}\text { Stenella } \\
\text { coeruleoalba }\end{array}$ & F & Adult & $188 \mathrm{~cm}$ & $68 \mathrm{~kg}$ & $\begin{array}{l}\text { Abdominal muscle and } \\
\text { pericardial parasitic nodules; } \\
\text { hemorrhages of the left eye; } \\
\text { splenomegaly }\end{array}$ & Mitral fibrosis & $\begin{array}{l}\text { Mitral endo- } \\
\text { cardiosis; Lambl's } \\
\text { excrescences }\end{array}$ \\
\hline 3 & $\begin{array}{l}\text { Stenella } \\
\text { coeruleoalba }\end{array}$ & M & Adult & $203 \mathrm{~cm}$ & $73 \mathrm{~kg}$ & $\begin{array}{l}\text { Subcutaneous hematoma } \\
\text { of left side of abdomen; } \\
\text { hemorrhages in left kidney; } \\
\text { hemoperitoneum; multifocal, } \\
\text { irregularly distributed, 2-mm } \\
\text { parasitic nodules scattered } \\
\text { throughout peritoneum }\end{array}$ & $\begin{array}{l}\text { Marked autolysis and } \\
\text { putrefaction }\end{array}$ & $\begin{array}{l}\text { Marked autolysis } \\
\text { and putrefaction }\end{array}$ \\
\hline 4 & $\begin{array}{l}\text { Stenella } \\
\text { coeruleoalba }\end{array}$ & M & Adult & $194 \mathrm{~cm}$ & $65 \mathrm{~kg}$ & Emphysema of the left lung & $\begin{array}{l}\text { Cirsoid aneurysms; } \\
\text { mitral leaflet } \\
\text { thickening }\end{array}$ & $\begin{array}{l}\text { Cirsoid aneurysm; } \\
\text { mitral endocar- } \\
\text { diosis; Lambl's } \\
\text { excrescences }\end{array}$ \\
\hline 5 & \begin{tabular}{|l|} 
Stenella \\
coeruleoalba
\end{tabular} & F & Adult & $203 \mathrm{~cm}$ & $76 \mathrm{~kg}$ & Absence of gross lesions & $\begin{array}{l}\text { Absence of gross } \\
\text { lesions }\end{array}$ & $\begin{array}{l}\text { Mitral } \\
\text { endocardiosis }\end{array}$ \\
\hline 6 & $\begin{array}{l}\text { Stenella } \\
\text { coeruleoalba }\end{array}$ & M & $\begin{array}{l}\text { Sub- } \\
\text { adult }\end{array}$ & $136 \mathrm{~cm}$ & $26 \mathrm{~kg}$ & $\begin{array}{l}\text { Emaciation; suppurative } \\
\text { bronchopneumonia; } \\
\text { suppurative mediastinal } \\
\text { lymphadenitis; intestinal and } \\
\text { omentum parasitic nodules }\end{array}$ & $\begin{array}{l}\text { Left ventricular } \\
\text { hypertrophy }\end{array}$ & $\begin{array}{l}\text { Mitral } \\
\text { endocardiosis; } \\
\text { Lambl's } \\
\text { excrescences }\end{array}$ \\
\hline 7 & \begin{tabular}{|l|} 
Stenella \\
coeruleoalba
\end{tabular} & M & Adult & $208 \mathrm{~cm}$ & $63 \mathrm{~kg}$ & $\begin{array}{l}\text { Emaciation; intestinal } \\
\text { adhesions }\end{array}$ & $\begin{array}{l}\text { Aneurysm of the right } \\
\text { sinus of Valsalva }\end{array}$ & $\begin{array}{l}\text { Aneurysm of right } \\
\text { sinus of Valsalva }\end{array}$ \\
\hline 8 & \begin{tabular}{|l|}
$\begin{array}{l}\text { Stenella } \\
\text { coeruleoalba }\end{array}$ \\
\end{tabular} & M & Adult & $205 \mathrm{~cm}$ & $73 \mathrm{~kg}$ & Severe parasitic pneumonia & $\begin{array}{l}\text { Absence of gross } \\
\text { lesions }\end{array}$ & $\begin{array}{l}\text { Absence of } \\
\text { microscopic lesions }\end{array}$ \\
\hline 9 & $\begin{array}{l}\text { Stenella } \\
\text { coeruleoalba }\end{array}$ & M & Adult & $192 \mathrm{~cm}$ & $70 \mathrm{~kg}$ & Fibrinous peritonitis & $\begin{array}{l}\text { Aneurysm of right } \\
\text { sinus of Valsalva; } \\
\text { mitral fibrosis }\end{array}$ & $\begin{array}{l}\text { Aneurysm of right } \\
\text { sinus of Valsalva }\end{array}$ \\
\hline 10 & $\begin{array}{l}\text { Tursiops } \\
\text { truncatus }\end{array}$ & M & $\begin{array}{l}\text { Sub- } \\
\text { adult }\end{array}$ & $181 \mathrm{~cm}$ & $\mathrm{NC}$ & Severe parasitic pneumonia & $\begin{array}{l}\text { Absence of gross } \\
\text { lesions }\end{array}$ & $\begin{array}{l}\text { Absence of } \\
\text { microscopic lesions }\end{array}$ \\
\hline
\end{tabular}


case 6, suppurative bronchopneumonia with suppurative mediastinal lymphadenitis was detected. Traumatic lesions were observed in 2 cases: hemorrhages of the left eye (case 2), and subcutaneous hematoma of the left side of the abdomen, hemorrhage in the left kidney and hemoperitoneum (case 3). Abdominal changes were observed in 4 cases: marble spleen and adrenal hypoplasia (case 1), splenomegaly (case 2), intestinal adhesions (case 7), and fibrinous peritonitis (case 9).

Gross cardiac pathology was observed in 6 of 10 animals, and histological lesions were found in 7 out of 10 dolphins. Findings are summarized in Table 1.

Macroscopic evaluation of the hearts in 3 cases $(1,7$, and 9) showed a white, elevated, well demarcated, ovoid area on the pulmonary artery adjacent to the pulmonary ostium in the pulmonary artery. These findings were classified as aneurysms of the pulmonary trunk and aneurysms of the right sinus of Valsalva. Histopathology of the affected pulmonary artery revealed marked diffuse mural atrophy on comparison to healthy control animals. In all observed

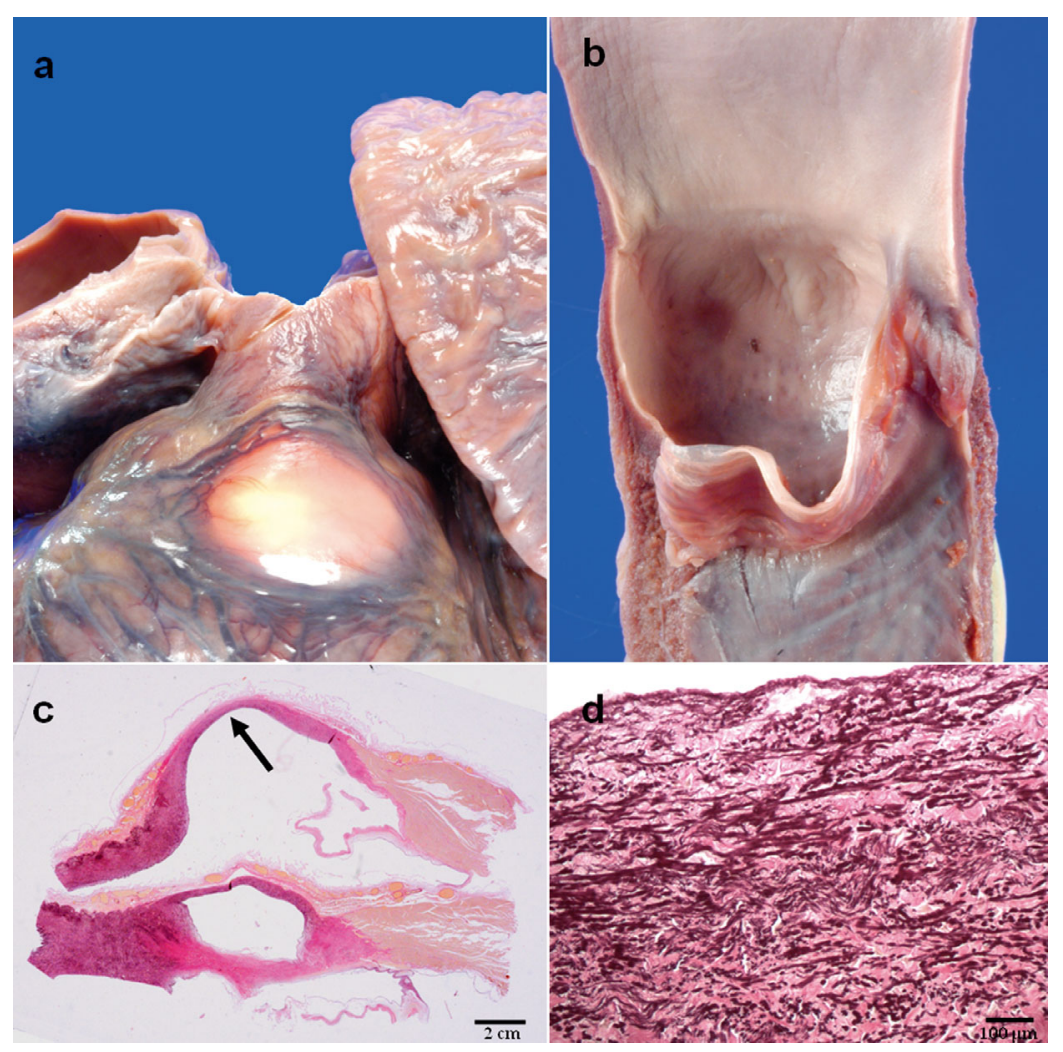

Fig. 1. Stenella coeruleoalba. Case no. 1, pulmonary artery: (a) white, elevated, well demarcated aneurysm of the right sinus of Valsalva; (b) endothelial surface of the aneurysm of the right sinus of Valsalva; (c) thinning of the pulmonary arterial wall (arrow) (Weigert-Van Gieson stain, WVG); (d) thick, shattered, and randomly arranged elastic fibers of the pulmonary arterial wall (WVG) cases, the wall of the pulmonary artery was atrophic (Fig. 1a,b) compared to a normal artery (Fig. 2).

One dolphin (case 1) had a dilated right ventricle, hypoplasia of the tricuspid chordae, severe and diffuse fibrosis associated with pronounced thickening and retraction of the tricuspid leaflets, and consequent left ventricle dilation. Adjacent to the papillary muscle in the interventricular septum, an intramural, firm, white spot, $0.2 \mathrm{~cm}$ in diameter, corresponding to focal interstitial lymphocytic myocarditis on histological examination, was also observed. Mitral valvular changes were observed in 3 cetaceans and included mitral fibrosis (case 2), mitral leaflet thickening (case 4), and left ventricular hypertrophy (case 6). Case 4 also presented a serpiginous course of the left subepicardial coronary artery which, at the cut surface, revealed dilated arteries surrounded by connective tissue, consistent with cirsoid aneurysm (Fig. 3a).

Histologically, the aneurysms of the pulmonary trunk (cases 1, 7, and 9) showed a thinner wall (Fig. 1c) compared to a normal vessel, and WVG staining revealed thick, shattered, and randomly arranged elastic fibers (Fig. 1d).

The walls of a limited number of cirsoid aneurysms of coronary arteries revealed the presence of intimal digitations. Necrosis and pyknosis were detected in smooth muscle cells and nuclei of the tunica media in some arteries in the absence of an inflammatory process, probably related to terminal metabolic changes. We did not detect arteriovenous anastomosis (Fig. 3b).

In 5 animals, histological examination of the mitral leaflets (cases 2,4-6) and of the tricuspid leaflets (case 1) showed thickening of the spongiosa characterized by proliferation of fibroblastic tissue, deposition of eosinophilic interstitial matrix, and degeneration of the fibrosa, with degeneration in the central fibrous core (Fig. 3c) consistent with endocardiosis. Four dolphins (cases 1, 2, 4, and 6) had small pointed projections from the edges of the valve cusps, comprised of connective tissue proliferations covered by endothelium, with variable aspect and shape that were identified as Lambl's excrescences (Fig. 3d). 


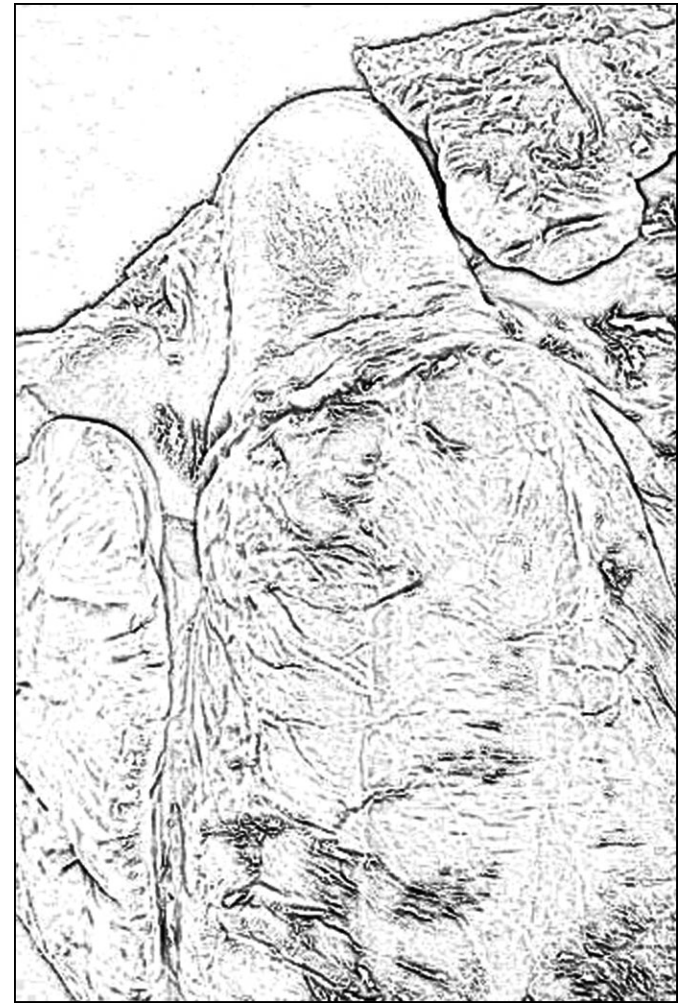

Fig. 2. Stenella coeruleoalba. Outline of a normal heart of a striped dolphin

\section{DISCUSSION}

Dolphin cardiac diseases show the same complexity as terrestrial mammals and humans, with interesting similarities and differences. In fact, fibrosis of the atrioventricular valves found in many of our stranded dolphins (cases 1, 2, 4-6) is comparable to that found in terrestrial mammals, and caused by previous injuries; the same applies for the hypoplasia of the chordae tendineae.

Lambl's excrescences represent a noteworthy finding. They were first described by Lambl (1856) and are represented by filiform fronds that form on the aortic surface atrioventricular valves, and anywhere in semilunar valves (Aziz \& Baciewicz 2007). In human pathology, Lambl's excrescences are fairly rare (Aziz \& Baciewicz 2007), while in veterinary medicine they have only been reported in horses (Else \& Holmes 1972, Guarda et al. 1997), and the exact pathogenetic mechanisms are not yet fully understood (Liu et al. 2012). Pomerance (1961) considered that Lambl's excrescences have their origin in endothelial damage, followed by minor fibrin deposition and organization, which may result in papillary proliferations. In contrast, Sinapius (1955) assumed that these excrescences develop from small, mostly
Fig. 3. Stenella coeruleoalba. (a) Case no. 4: cut surface of the left subepicardial coronaric artery: cirsoid aneurysm; (b) case 4: histological features of cirsoid aneurysm: dilation, twisting, lengthening of the coronary artery surrounded by connective tissue; (c) case 5: thickening of the mitral spongiosa caused by myxoid degeneration in the central fibrous core (hematoxylin and eosin stain, HE); inset: higher magnification of the myxoid degeneration (HE); (d) case 6: Lambl's excrescences (HE)
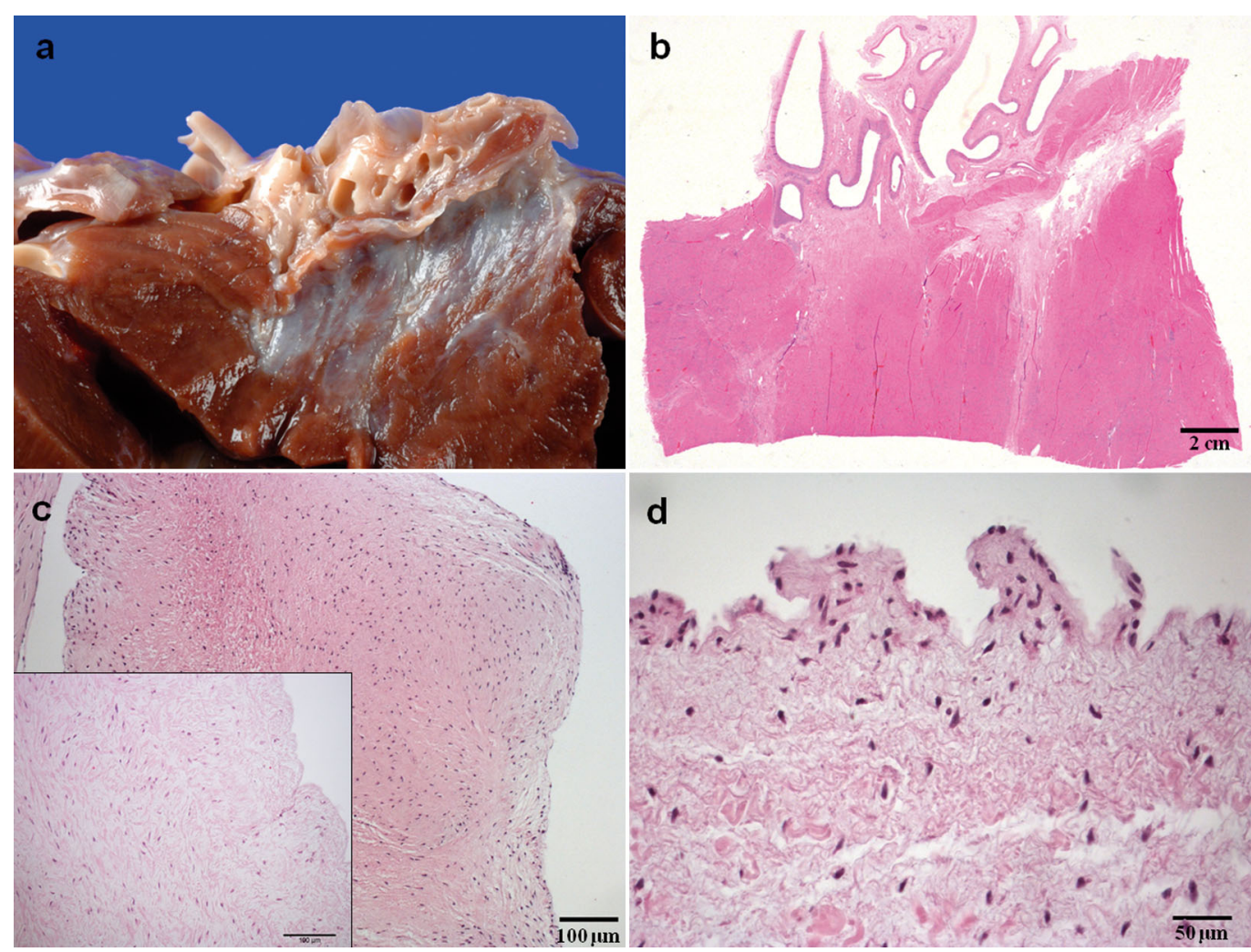
fibrinous thrombi. Lambl's excrescences have the potential to embolize to distant organs and, although it has not yet been fully clarified (Melduni et al. 2008), a correlation between the presence of Lambl's excrescences and neurological signs (such as confusion and disorientation) has been hypothesized (Aziz \& Baciewicz 2007). Although most patients with this pathology are asymptomatic, Lambl's excrescences can break apart and embolize to the brain, causing strokes and cerebrovascular lesions. We found Lambl's excrescences in 4 stranded dolphins, but embolization within the examined tissues was not observed. These findings should be taken into account as a possible cause of dolphin strandings.

The finding of aneurysms of the pulmonary trunk in 3 dolphins is significantly relevant. Martineau et al. (1986) previously described a case of rupture of a dissecting false aneurysm of the pulmonary trunk in a beluga wale Delphinapterus leucas associated with verminous pneumonia. Histologically, islets of red cells dissect the media, with fibrin, edema, and collagen fiber deposition, resulting in disorganized and fragmented elastic fibers in the media. In our study, the aneurysms of the pulmonary trunk are analogous to human aneurysms of the sinus of Valsalva, a rare cardiac anomaly in human pathology (Mohite et al. 2012), which can be acquired or congenital (Huh et al. 2012). The congenital variety is due to failure of fusion between the aortic media and the heart at the annulus fibrosus of the aortic valve. In fact, in humans, congenital absence of the tunica media of the aortic wall behind the sinus of Valsalva can cause an aneurysmal dilation (Edwards \& Burchell 1957).

Another interesting finding presented in this study is the presence of cirsoid aneurysms in a dolphin. Cirsoid aneurysms of the coronary arteries are congenital malformations that have occasionally been observed in bovines and more rarely in horses and swine (Drommer 1991, Marcato 2002). The coronary arteries were dilated, intertwined in the outer zones of the myocardium, and concamerated.

Although not speciated, the parasitic nodules throughout the epicardium in one of our cases would likely not have contributed to dysrhythmias, cardiovascular compromise, or the death of this dolphin. Further investigations are needed to better evaluate their role in dolphin pathology.

To our best knowledge, Lambl's excrescences, aneurysms of the pulmonary trunk, and cirsoid aneurysms have not been previously described in marine mammals, and some of these findings should be taken into account as possible causes of dolphin strandings. Furthermore, the hearts of marine mam- mals need to be studied more carefully to evaluate similarities and differences compared to lesions of terrestrial mammals and humans. Further studies should include the analysis of a greater number of cetacean hearts in order to obtain statistically significant numbers to correlate with the age of the subjects and other concomitant diseases, and to correlate heart lesions to other systemic changes (i.e. lung, liver, and central nervous system).

Acknowledgements. We thank the Centro di Referenza di Patologia Comparata 'Bruno Maria Zaini,' Italy.

\section{LITERATURE CITED}

Aziz F, Baciewicz FA Jr (2007) Lambl's excrescences: review and recommendations. Tex Heart Inst J 34:366-368

Bossart GD, Hensley G, Goldstein JD, Kroell K, Manire CA, Defran RH, Reif JS (2007) Cardiomyopathy and myocardial degeneration in stranded pygmy (Kogia breviceps) and dwarf (Kogia sima) sperm whales. Aquat Mamm 33: 214-222

Drommer W (1991) Kreislauforgane. In: Schulz LC (ed) Pathologie der Haustiere. Fischer, Jena

Edwards JE, Burchell HB (1957) The pathological anatomy of the deficiencies between the aortic root and the heart including aortic sinus aneurysms. Thorax 12:125-139

Else RW, Holmes JR (1972) Cardiac pathology in the horse. 2. Microscopic pathology. Equine Vet J 4:57-62

Finkbeiner WE, Russell PC, Davis RL (2009) Autopsy pathology: a manual and atlas. Sounders, Philadelphia, PA, p 175-183

Gray KN, Conklin RH (1974) Multiple births and cardiac anomalies in the bottle-nosed dolphin. J Wildl Dis 10: 155-157

Guarda F, Rattazzi C, Donn A, Gagna L (1997) The 'Lambl's excrescences' in the mitral valve of the horse. Eur J Vet Pathol 3:103-105

Guzmán-Verri C, González-Barrientos R, Hernández-Mora G, Morales JA, Baquero-Calvo E, Chaves-Olarte E, Moreno E (2012) Brucella ceti and brucellosis in cetaceans. Front Cell Infect Microbiol 2:3

- Huh SJ, Park TH, Lee DY, Kang H and others (2012) A giant unruptured right coronary sinus of Valsalva aneurysm. J Cardiovasc Ultrasound 20:60-62

Jardine JE, Dubey JP (2002) Congenital toxoplasmosis in a [sic] Indo-Pacific bottlenose dolphin (Tursiops aduncus). J Parasitol 88:197-199

Lambl VD (1856) Papillare Excrescenzen an der SemilunarKlappe der Aorta. Wien Med Wochenschr 6:244-247

Liu RZ, Yu SY, Li Y (2012) Migraine-like headache and ischemic strokes in two patients with Lambl's excrescences. Chin Med J (Engl) 125:3346-3348

Marcato PS (2002) Patologia sistematica veterinaria. Edagricole, Bologna

Martineau D, Lagacé A, Béland P, Desjardins C (1986) Rupture of a dissecting aneurysm of the pulmonary trunk in a beluga whale (Delphinapterus leucas). J Wildl Dis 22: 289-294

Melduni RM, Klarich KW, Nesbitt GC, Shub C (2008) Lambl's excrescences: Is surgical excision really necessary? Tex Heart Inst J 35:89-90 
Mohite PN, Rohit MK, Thingnam SK (2012) Ruptured right sinus of Valsalva into main pulmonary artery. J Cardiovasc Dis Res 3:132-134

Neurohr B (1982) Herzfehler bei einem großen Tümmler (Tursiops truncatus). Verhandlungsber Int Symp Erkrankungen Zootiere 24:55-56

Pomerance A (1961) Papillary 'tumours' of the heart valves. J Pathol Bacteriol 146:404-410

Powell JW, Archibald RT, Cross CA, Rotstein DS, Soop VM, McFee WE (2009) Multiple congenital cardiac abnormalities in an Atlantic bottlenose dolphin (Tursiops truncatus). J Wildl Dis 45:839-842

Sedmera D, Misek I, Klima M, Thompson RP (2003) Heart development in the spotted dolphin (Stenella attenuata). Anat Rec 273A:687-699

Editorial responsibility: Michael Moore, Woods Hole, Massachusetts, USA
Sinapius D (1955) Zur formalen Genese der Lamblschen Excrescenzen. Virchows Arch 326:387-408

Slijper J (1961) Foramen ovale and ductus arteriosus Botalli in aquatic mammals. Mammalia 25:528-570

Troncone A, Zizzo N (1994) Malformazione cardiovascolare in un delfino (Stenella coeruleoalba). Obiettivi Documenti Vet 15:67-68

Turnbull BS, Cowan DF (1998) Myocardial contraction band necrosis in stranded cetaceans. J Comp Pathol 118: 317-327

Virchow RLK (1880) A description and explanation of the method of performing post-mortem examinations in the dead-house of the Berlin Charité hospital, with especial reference to medico-legal practice. Churchill, London

Submitted: October 31, 2012; Accepted: September 13, 2013 Proofs received from author(s): November 15, 2013 